\title{
CHANGES IN SOFT-BOTTOM MACROBENTHIC ASSEMBLAGES AFTER A SULPHURIC ACID SPILL IN THE RIO GRANDE HARBOR (RS, BRAZIL)
}

\author{
BEMVENUTI, C. E., ${ }^{1}$ ROSA-FILHO, J. S. ${ }^{1}$ and ELLIOTT, M. ${ }^{2}$ \\ ${ }^{1}$ Laboratório de Ecologia de Invertebrados Bentônicos, Departamento de Oceanografia, \\ FURG, C.P. 474, CEP 96201-490, Rio Grande, RS, Brazil \\ ${ }^{2}$ Institute of Estuarine and Coastal studies, Hull, HU, and RX, UK \\ Correspondence to: Carlos Emílio Bemvenuti, Laboratório de Ecologia de Invertebrados Bentônicos, Departamento \\ de Oceanografia, FURG, C.P. 474, CEP 96201-490, Rio Grande, RS, Brazil, e-mail: docbemve@ furg.br \\ Received May 29, 2002 - Accepted September 11, 2002 - Distributed May 31, 2003
}

(With 6 figures)

\begin{abstract}
The structure of macrobenthic assemblages in Rio Grande Harbor was analyzed during and after a sulphuric acid spill in August 1988. Five stations were sampled four times between September 1988 and March 1999. At each station, three samples were taken using a van Veen grab $\left(0.078 \mathrm{~m}^{2}\right)$. A total of 22 taxa were collected including Crustacea (9 spp.), Polychaeta (7 spp.), Mollusca ( 3 spp.), Phoronida (1 sp.), Nemertinea (1 sp.), and Plathyelminthea (1 sp.). The macrobenthic assemblages suffered different impacts depending on station location and time: 1) immediate impact, i.e., during acid discharge, as at the station nearest $(250 \mathrm{~m})$ the acid spill source; 2$)$ impact some time after the discharge, as at the station $500 \mathrm{~m}$ downstream from the acid spill source; and 3) absence of direct impact on the remaining sampling points, on the discharge area outer limit. The macrobenthic assemblage recovered six months after the sulphuric acid spill.
\end{abstract}

Key words: macrobenthic assemblage, acid spill, harbor, Patos Lagoon.

\section{RESUMO}

\section{Estrutura das associações de macroinvertebrados bentônicos de fundos moles após um derrame de ácido sulfúrico no Porto de Rio Grande, RS, Brasil}

A estrutura das associações de macroinvertebrados bentônicos na área do Porto de Rio Grande foi comparada durante e após um derrame de ácido sulfúrico ocorrido em agosto de 1988. Cinco estações de coleta foram amostradas por 4 vezes entre setembro de 1988 e março de 1989. Em cada estação foram tomadas três amostras com um pegador van Veen $\left(0,078 \mathrm{~m}^{2}\right)$. Foram coletadas 22 taxa: Crustacea (9 spp.), Polychaeta (7 spp.) Mollusca (3 spp.), Phoronida (1 sp.), Nemertinea (1 sp.) e Platyelminthea (1 sp.). As associações macrozoobentônicas foram submetidas a impactos de distinta magnitude de acordo com os locais ou períodos das amostragens: 1) impacto imediato, isto é, durante o período de derramamento do ácido, na estação mais próxima $(250 \mathrm{~m})$ do ponto de descarga; 2) impacto na estação logo após o período de derramamento, $500 \mathrm{~m}$ a jusante do ponto de descarga; e 3) ausência de impacto nas estações mais afastadas do ponto de descarga. Seis meses após o derrame, verificouse a recuperação da associação de macroinvertebrados bentônicos.

Palavras-chave: macrozoobentos, derrame de ácido, porto, Lagoa dos Patos. 


\section{INTRODUCTION}

On August 25, 1998, the Maltese ship NT Bahamas docked at the Rio Grande Harbor to unload approximately 12,000 metric tons of concentrated sulphuric acid $\left(\mathrm{H}_{2} \mathrm{SO}_{4}\right)$. Technical problems onboard the vessel resulted in internal damage to the ship, requiring immediate release of the acid mixture into the Rio Grande Channel (Montú \& Gloeden, 1998). This discharge was controlled, with release to the environment only during ebb tide at a minimum discharge velocity of $20 \mathrm{~cm} \cdot \mathrm{s}^{-1}$, and with continuous monitoring of the water $\mathrm{pH}$ in the channel (Dr. Luís F. Niencheski, Dept. of Chemistry, FURG, and Dr. Osmar O. Möller, Dept. of Physics, FURG, pers. comm.). This incident offered a unique opportunity to study the effects of acid discharges on soft bottom macrobenthic communities in estuarine regions.

Even considering that $\mathrm{pH}$ is an important determinant of aquatic species distribution patterns (Abel, 1996), reviews which include many case studies of aquatic environmental pollution contain none on the effects of acid discharge on the structure and dynamics of macrobenthic assemblages in estuarine regions. Such studies are usually restricted to acidification situations in limnic environments (Price \& Swift, 1985; Shaw \& Mackie, 1990; Lonergan \& Rasmussen, 1996) or to experiments on the $\mathrm{pH}$ tolerance of commonly farmed species (Pillay, 1993). This study compares the composition, species richness, and density of the soft bottom macrobenthic assemblages along a gradient of distance from the spill in Rio Grande Harbor during and after the sulphuric acid discharge from the NT Bahamas.

\section{STUDY AREA}

The Rio Grande Harbor is located in the estuarine region of the Patos Lagoon (Southern Brazil) (Fig. 1). This extensive coastal lagoon is $250 \mathrm{~km}$ long and has a maximum width of $60 \mathrm{~km}$, covering a $10,360 \mathrm{~km}^{2}$ area along the coastal plain of Rio Grande do Sul.

The estuarine region (sensu Closs, 1962) is restricted to the southern portion of the lagoon and corresponds to $10 \%$ of its total. The area is subject to a microtidal regime (tidal range $<1.0 \mathrm{~m}$ ), and large fluctuations in water level and salinity are mainly associated with changes in meteorological conditions, such as rainfall and wind direction (Garcia, 1997; Niencheski \& Baumgarten, 1997). In this region, winter and spring are usually the rainy seasons, and autumn and summer the dry ones. During the winter and spring, a conjunction of NE winds with high rainfall can cause a salinity decrease to values near 0 for a long time in the whole estuary (Baumgarten \& Niencheski, 1990). In the autumn and summer during minimal freshwater discharges and with SW winds, salinity can reach values near 34 in the estuary's southern portion (Bemvenuti \& Netto, 1998).

\section{MATERIAL AND METHODS}

Samples were collected at five locations (Fig. 1) on: September 8 and 14, 1998, when the acid mixture was being discharged in the channel; November 6 and 24, 1998, approximately two months after the spill; and March 23, 1999, six months after the event.

Station 1 was located approximately $250 \mathrm{~m}$ downstream from the acid spill source (32 3'225's, $\left.52^{\circ} 4^{\prime} 263^{\prime \prime} \mathrm{W}\right)$, and station 2 at approximately 500 $\mathrm{m}$ downstream from the discharge (323'655' $\mathrm{S}$, $52^{\circ} 4^{\prime} 973$ 'W). The depth at both stations was $4 \mathrm{~m}$. Stations 3 (32'4'475'S, 52 5'458'W, 4 m depth)

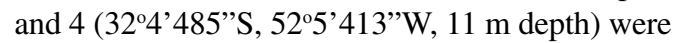
positioned on the outer limit of what was considered the acid plume's zone of influence, the extension of which was determined by the addition of rhodamine to the water, followed by fluorescence spectroscopy, thus making it possible to define the dispersion and advection of the reddish stain, as well to detect $\mathrm{pH}$ values near neutral (Dr. Luís F. Niencheski, Dept. of Chemistry, Fundação Universidade do Rio Grande (FURG) and Dr. Osmar O. Möller, Dept. of Physics, FURG, pers. comm.). Station 5 was located $5 \mathrm{~km}$ downstream from the acid spill source (32 $\left.5^{\prime} 941^{\prime \prime} \mathrm{S}, 52^{\circ} 6^{\prime} 119^{\prime \prime} \mathrm{W}\right)$ and was chosen for its greater depth $(18 \mathrm{~m})$ (Fig. 1).

Sampling occurred at all five stations on each cruise with the exception of the first in November when, due to technical reasons, only the first threestations were sampled. Three samples were collected at each site using a van Veen grab $(19 \times 41 \times 19 \mathrm{~cm})$. The collected material was sieved onboard with a $0.5 \mathrm{~mm}$ nylon mesh to retain the macrofauna (Holme \& McIntyre, 1984), and the captured organisms were fixed in $10 \%$ formalin in seawater. 


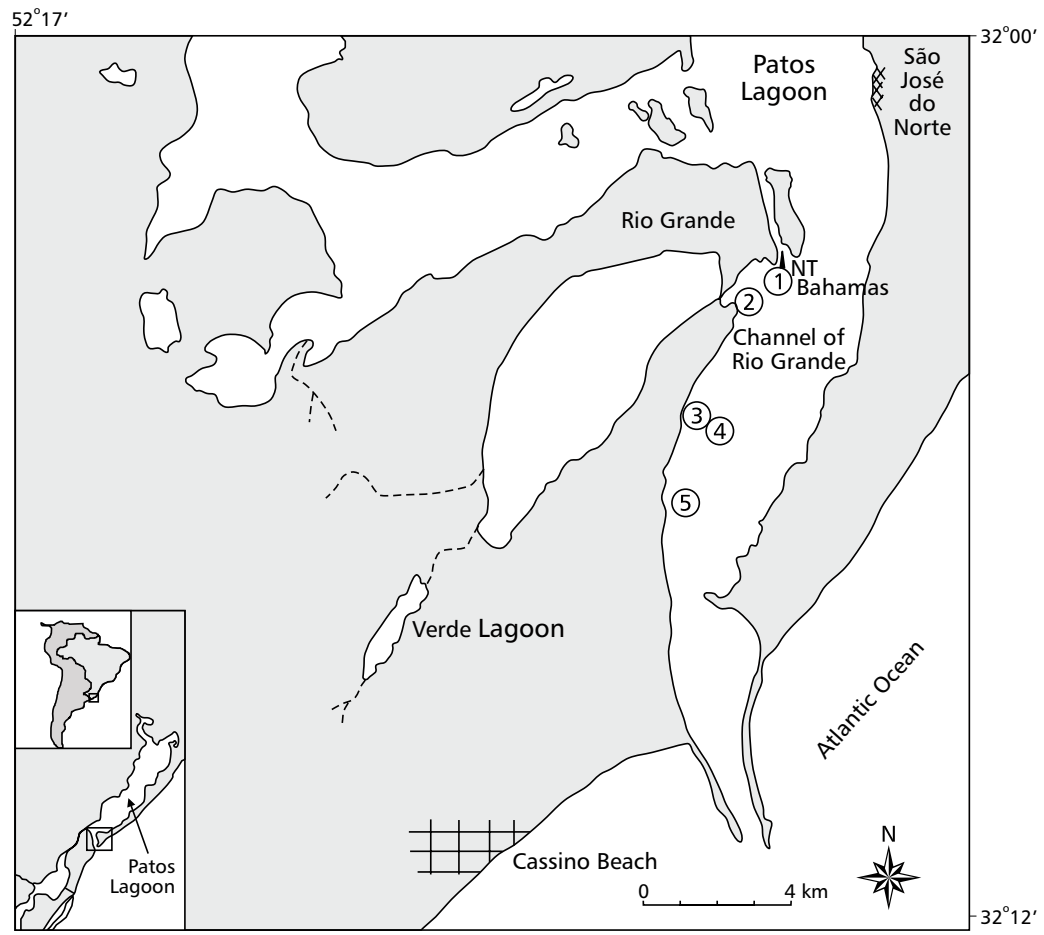

Fig. 1 - Map of the study area showing the sampling stations (numbers 1 to 5).

During (September 8-14, 1998) and after (November 6-12, 1998) the acid discharge, Dr. Paulo M. Baisch (Geochemistry Laboratory of the Geosciences Department, FURG) measured the $\mathrm{pH}$ and Eh in surface sediments, at the same stations where the biological samples were collected, using a $\mathrm{pH} /$ Eh meter (model DM2, Digimed), in addition to collecting sediment to determine its textural characteristics. The same methods were used to measure $\mathrm{pH}$ and $\mathrm{Eh}$ in the surface sediments during the March cruise.

In the laboratory, the biological material was stained with the vital stain bengal rose, sorted, identified to the lowest possible taxon, and preserved in $70 \%$ ethanol. The species richness and total density (expressed in number of individuals $0.078 \mathrm{~m}^{-2}$ ) were determined for each species in each biological sample.

The densities of the dominant species (considered as those with more than 10 individuals in the sum of the three replicates) and of the total number of organisms were compared through a 1way Analysis of Variance, using sampling dates as the factor. Prior to performing the analysis, data normality and variance homogeneity were tested using the Kolmogorov-Smirnov \& Levene tests, respectively. Since the above tests revealed the absence of homogeneity in the variances, the data were transformed using the fourth root of the abundance values, as proposed by Clarke \& Warwick (1994). In the cases where the analysis exhibited statistically significant differences $(\mathrm{p}<0.05)$, the mean values were compared by the post-hoc test of Scheffé. A hierarchical cluster analysis was performed, based on the fourth root-transformed abundance data, in order to determine the site-data stations' similarity. The similarity index of Bray-Curtis was used employing the UPGMA amalgamation method as proposed by Field et al. (1982). Statistical analyses were performed using the software STATISTICA ${ }^{\circledR}$ 98 edition and PRIMER 5.0. 


\section{RESULTS}

A total of 22 taxa were identified at the five sampling stations for the samples collected in September, November, and March ( $\mathrm{n}=54$ samples). The composition had a predominance of crustacean (9 species), followed by Polychaeta (seven species),
Mollusca (three species), one Nemertinea, one Platyhelminthes, and one Phoronida (Table 1).

Tables 2 and 3 show the sediment textural characteristics and $\mathrm{pH}$ and $\mathrm{Eh}$ values measured during and after the discharge. These indicate that the sediment was composed mainly of fine sands with a high proportion of silt and clay.

TABLE 1

Species composition throughout the cruises at each sampling station.

\begin{tabular}{|c|c|c|c|c|c|c|c|c|c|c|c|c|c|c|c|c|c|c|c|c|}
\hline \multirow[b]{3}{*}{ Specific composition } & \multicolumn{20}{|c|}{ Cruises and stations $^{\mathrm{a}}$} \\
\hline & \multicolumn{5}{|c|}{ September } & \multicolumn{5}{|c|}{ November $1^{b}$} & \multicolumn{5}{|c|}{ November 2} & \multicolumn{5}{|c|}{ March } \\
\hline & 1 & 2 & 3 & 4 & 5 & 1 & 2 & 3 & $*$ & $*$ & 1 & 2 & 3 & 4 & 5 & 1 & 2 & 3 & 4 & 5 \\
\hline \multicolumn{21}{|l|}{ Mollusca } \\
\hline Heleobia australis & - & - & - & - & - & & - & - & & & - & - & - & - & - & - & - & - & - & - \\
\hline Erodona mactroides & - & - & - & - & - & & - & - & & & - & - & - & - & - & & - & - & & \\
\hline Tagelus plebeius & & - & & & & & & & & & & - & - & & & & & & & \\
\hline \multicolumn{21}{|l|}{ Polychaeta } \\
\hline Heteromastus similis & - & - & - & - & - & - & - & - & & & - & - & - & - & - & - & - & - & - & \\
\hline Nephtys fluviatilis & - & - & - & - & - & - & - & - & & & & - & - & - & & - & - & - & - & - \\
\hline Neanthes bruaca & & & & & - & & & - & & & & & & - & & & & - & - & - \\
\hline Bocardia hamata & & - & - & & & & & & & & & & & & & & & & & \\
\hline Drilonereis tenuis & & & & & & & & & & & & & & & & - & & - & - & \\
\hline Sigambra grubii & & & & & & & & & & & & & & & & - & & - & - & - \\
\hline Americonuphys sp. & & & & & & & & & & & & & & & & & & & & - \\
\hline \multicolumn{21}{|l|}{ Crustacea } \\
\hline Kalliapseudes schübartii & - & - & - & - & - & - & - & - & & & & - & - & - & - & - & - & - & - & _- \\
\hline Tanais stanfordi & & - & - & & & & & & & & & - & - & - & & & & & & \\
\hline Munna peterseni & & - & & & & & & & & & & & - & - & & & & & & \\
\hline Kupellonura sp. & - & - & - & - & & - & - & - & & & & & - & & & & & - & & \\
\hline Paracorophium sp. & & & - & & - & & & & & & & & & & & & & & & \\
\hline Bathyporeiapus bisetosus & & & - & & & & & & & & & - & & & & & & & & \\
\hline Leptocheirus sp. & & & & & - & & & & & & & & & & & & & & & \\
\hline Dyastilis sympterigiae & & & - & & & - & - & - & & & & & - & & & & & & & \\
\hline Cyrtograpsus angulatus & & & & & & & & & & & & & & & & & & & - & - \\
\hline \multicolumn{21}{|l|}{ Phoronida } \\
\hline Phoronis psamophyla & & & & & & & & & & & & & & & & & - & & & \\
\hline \multicolumn{21}{|l|}{ Platyhelminthes } \\
\hline Turbellaria & & & & - & & & & & & & & & & & & & & & & \\
\hline \multicolumn{21}{|l|}{ Nemertina } \\
\hline Nemertineo & & & & & & & & - & & & & - & - & & & & - & & - & _- \\
\hline
\end{tabular}


The $\mathrm{pH}$ and Eh measurements clearly show changes in these parameters with acidification and elevation of the redox potential at the two stations closest to the ship during the discharge. In November and March, the $\mathrm{pH}$ values were close to neutral and the Eh values were weakly reductive as is normal in the Lagoa dos Patos estuarine waters. Station 3 displayed the highest species richness in the four cruises (between 9 and 11 taxa) and conversely, the lowest value ( 3 species) was recorded at the end of November at station 1 , the closest to the spill (Table 1). The highest average density of organisms $(3,964$ ind. $0.078 \mathrm{~m}^{-2}$ ) was recorded at station 4 in March 1999; conversely, the lowest density was recorded at station 1 where only 6 ind $0.078 \mathrm{~m}^{-2}$ occurred on the first cruise in November 1998 (Fig. 2).

TABLE 2

Summary of the main sediment characteristics at each sampling station (data from Dr. Paulo Baish, Geochemistry Laboratory, FURG).

\begin{tabular}{|c|c|c|c|c|}
\hline \multirow{2}{*}{ Stations } & \multicolumn{4}{|c|}{ Granulometric fractions } \\
\cline { 2 - 5 } & Sand \% & Silt \% & Clay \% & Silt + Clay \% \\
\hline $\mathbf{1}$ & 52.92 & 27.68 & 19.40 & 47.08 \\
\hline $\mathbf{2}$ & 41.37 & 34.53 & 24.10 & 58.63 \\
\hline $\mathbf{3}$ & 38.75 & 35.85 & 25.40 & 61.25 \\
\hline $\mathbf{4}$ & 17.55 & 20.86 & 61.59 & 82.45 \\
\hline $\mathbf{5}$ & 18.60 & 23.18 & 58.22 & 81.40 \\
\hline
\end{tabular}

${ }^{1}$ Mean values from four cruises.

TABLE 3

Values of pH and Eh in the surface of sediments measured during and after the acid spill at each sampling station (data from Dr. Paulo Baish, Geochemistry Laboratory, FURG).

\begin{tabular}{|c|c|c|c|c|c|c|c|c|c|c|c|c|c|c|}
\hline \multirow{3}{*}{ Stations } & \multicolumn{10}{|c|}{ Darameters $^{\mathbf{a}}$} \\
\cline { 2 - 16 } & \multicolumn{10}{|c|}{} & \multicolumn{10}{|c|}{ After the spill } \\
\cline { 2 - 16 } & $\mathbf{p H}$ & $\mathbf{E h}$ & $\mathbf{p H}$ & $\mathbf{E h}$ & $\mathbf{p H}$ & $\mathbf{E h}$ & $\mathbf{p H}$ & $\mathbf{E h}$ & $\mathbf{p H}$ & $\mathbf{E h}$ & $\mathbf{p H}$ & $\mathbf{E h}$ & $\mathbf{p H}$ & $\mathbf{E h}$ \\
\hline $\mathbf{1}$ & 5.21 & 21 & 4.39 & -3 & 4.45 & 75 & 4.36 & 42 & 6.26 & -115 & 7.02 & -155 & 7.25 & -146 \\
\hline $\mathbf{2}$ & 5.83 & -38 & 5.20 & 26 & 5.56 & 26 & 5.10 & 26 & 6.42 & -136 & 6.76 & -108 & 7.15 & -113 \\
\hline $\mathbf{3}$ & 6.15 & -30 & 6.00 & 88 & 6.05 & -76 & 6.72 & -85 & 6.35 & -85 & 6.88 & -88 & 7.35 & -125 \\
\hline $\mathbf{4}$ & 6.53 & -101 & 6.65 & -115 & 6.89 & -81 & 6.65 & -90 & 6.68 & -64 & 7.21 & -128 & 7.25 & -118 \\
\hline $\mathbf{5}$ & 6.99 & -15 & 6.91 & -62 & 7.01 & -100 & 6.91 & -86 & 6.80 & -64 & 7.26 & -58 & 7.75 & -133 \\
\hline
\end{tabular}

${ }^{\mathrm{a}} \mathrm{Eh}(\mathrm{mV}) ;{ }^{\mathrm{b}}$ four cruises carried out on September 8, 10, 12, and 14,$1998 ;{ }^{\mathrm{c}}$ three cruises, after the spill, on November 6 and 12, 1998, and March 23, 1999. 


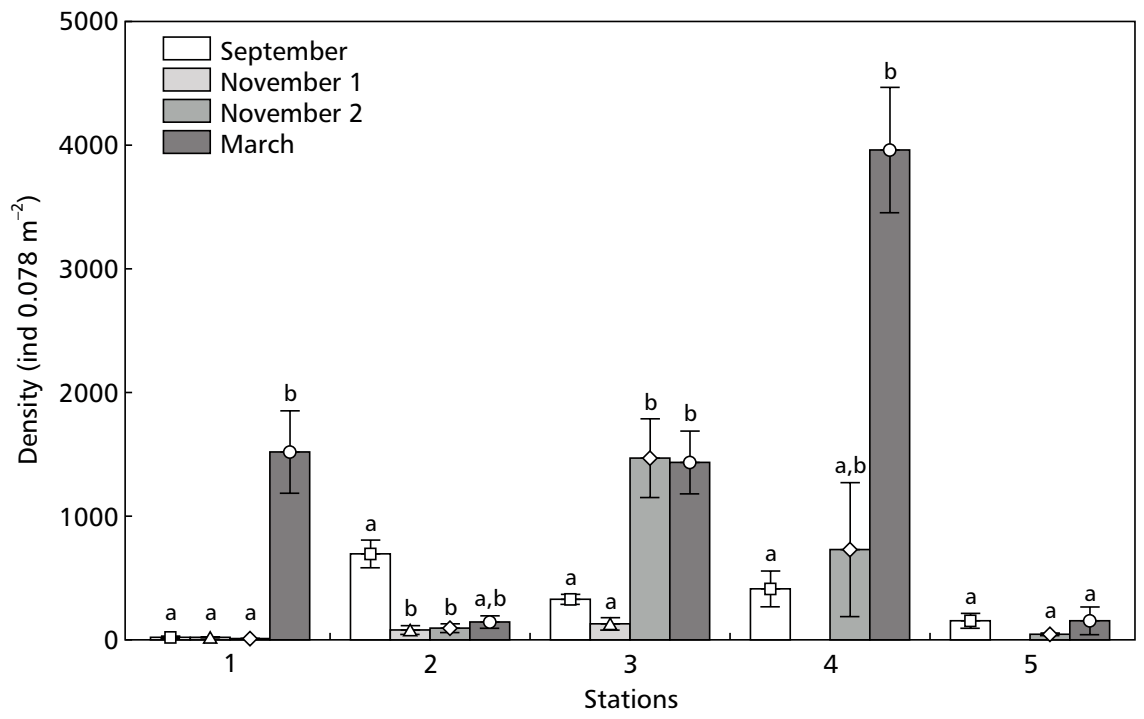

Fig. 2 - Means and standard errors of the total number of organisms in the sampling stations throughout the cruises. Different letters denote significant statistical differences among cruises $(\mathrm{p}<0.05)$.

Station 1 exhibited a low number of benthic macroinvertebrates during the first three cruises (Fig. 2). At this station, the only species that maintained a relative stable density at the end of November, albeit displaying a high value on the standard error of the mean, was the polychaete Heteromastus similis (Fig. 3). This station showed a recovery of macrobenthic assemblages by March 1999, with an increase in the number of species and total density of organisms (Fig. 2, Table 1).

Station 2, with a high total density value in September, showed a significant reduction in abundance of benthic macrofauna during November (Fig. 2). This station showed a large-scale reduction in density of the gastropod Heleobia australis in the samples collected in November 1998, with no recovery by March 1999 (Fig. 4).

Station 3 exhibited a significant total density increase in organisms at the end of November (Fig. 2) compared with results of the September cruise and the first one in November. This was mainly determined by a strong recruitment of $H$. australis (Fig. 4) and the tanaid Kalliapseudes schübartii (Fig. 5). The samples in this period revealed that more than $60 \%$ of the individuals of these two species were newly settled juveniles. Similarly, in March the high macrobenthic densities at station 3 (Fig. 2) were mainly the effect of abundant $H$. australis (Fig. 4).

At station 4, there was an increase in total organism density between September and March (Fig. 2), largely caused by high densities of $H$. australis (Fig. 4). Station 5 showed H. australis to be the dominant species and exhibited a reduction in the total benthic macroinvertebrate density in the cruise carried out at the end of November (Fig. 6). This station had a substratum with distinct characteristics between the September and March cruises when compared to that of November in which the samples showed sediment with a high concentration of biogenic sediment particles, mainly shell fragments.

The Fig. 6 shows the result of a cluster analysis revealing the formation of four groups at a $60 \%$ similarity level. Groups 1 and 2 were composed of samples from station 1 from the September and November cruises, and samples from station 5 from the second one in November. These groups were characterized by a paucity of species and the lowest organism density. Group 1 , dominated by $H$. australis and $H$. similis, presented a total of 4 species. Group 2, dominated by $K$. schübartii and the polychaete Nephtys fluviatilis, had 8 species. 


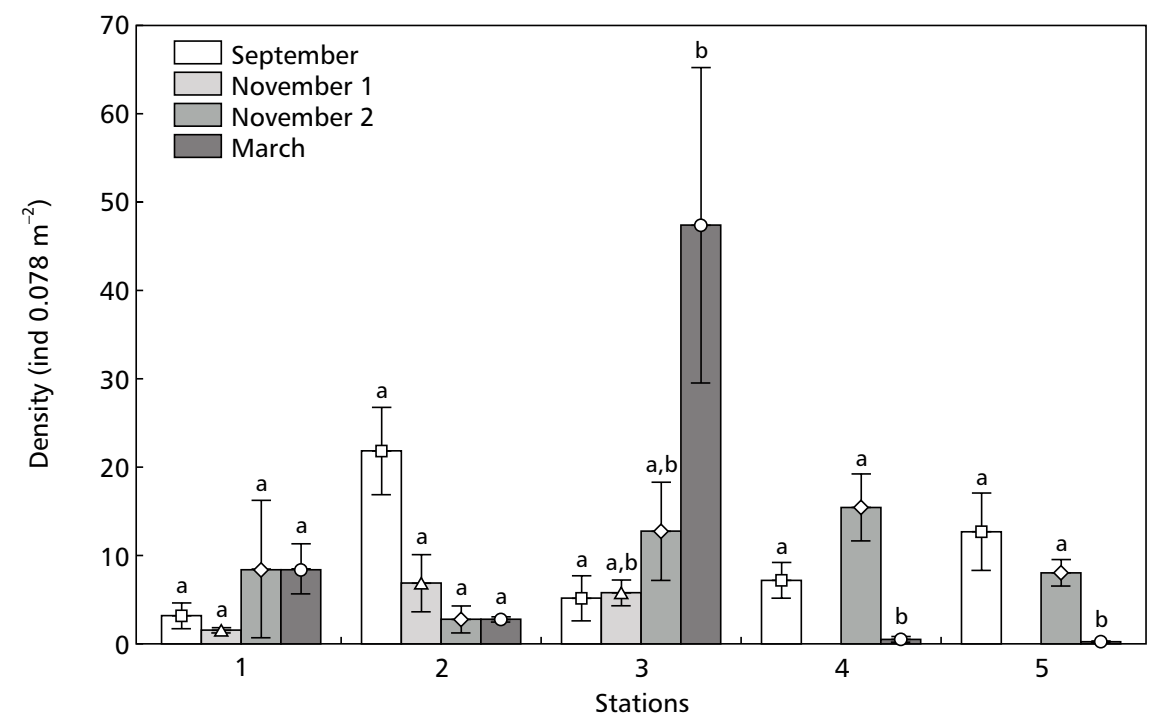

Fig. 3 - Means and standard errors of the density of Heteromastus similis in the sampling stations throughout the cruises. Different letters denote significant statistical differences among cruises $(\mathrm{p}<0.05)$.

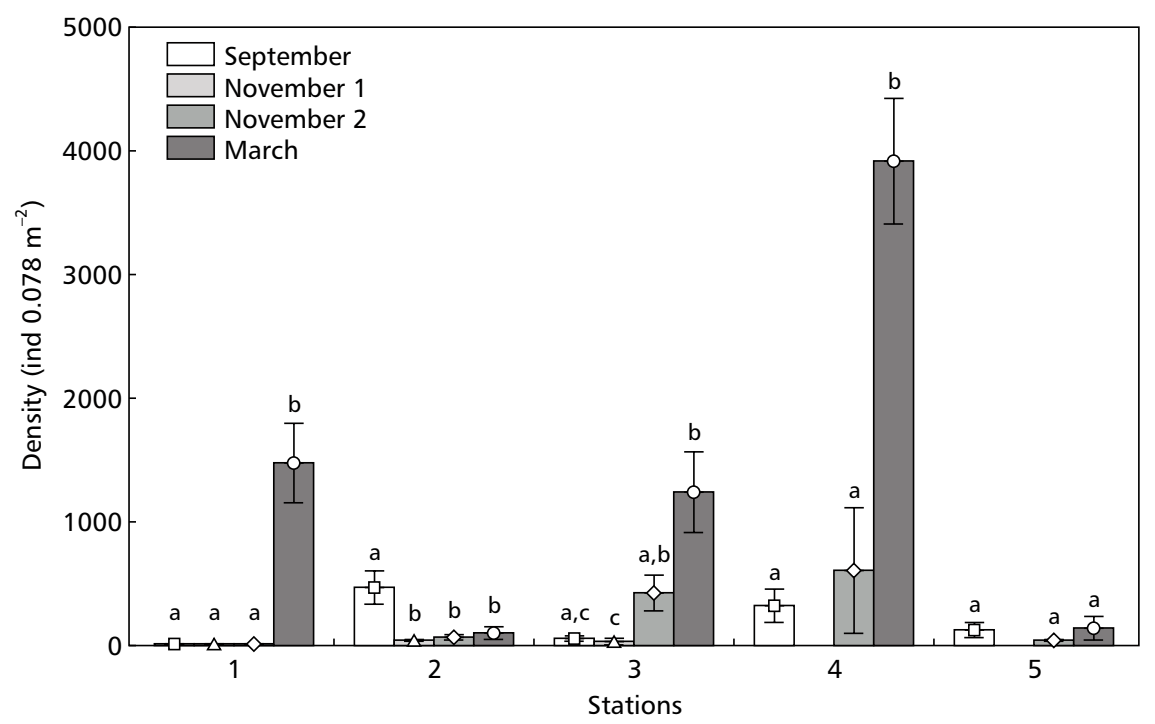

Fig. 4- Means and standard errors of the density of Heleobia australis in the sampling stations throughout the cruises. Different letters denote significant statistical differences among cruises $(\mathrm{p}<0.05)$. 


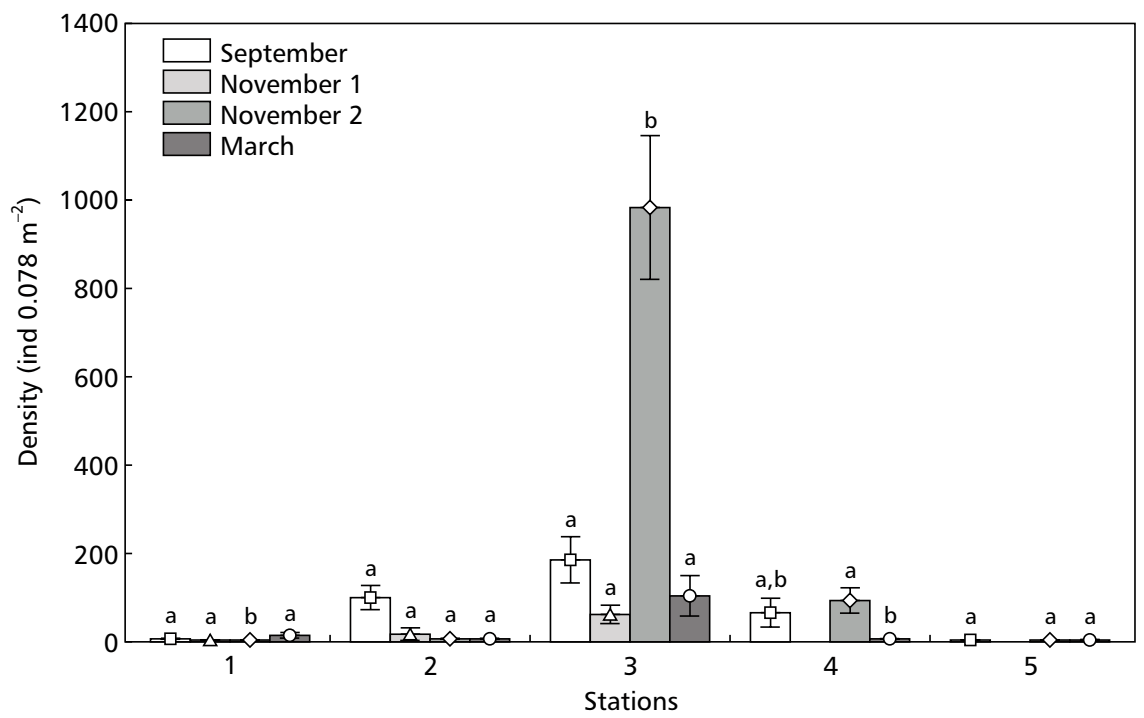

Fig. 5 - Means and standard errors of the density of Kalliapseudes schübartii in the sampling stations throughout the cruises. Different letters denote significant statistical differences among cruises $(\mathrm{p}<0.05)$.

Group 3 was subdivided into subgroups $3 \mathrm{a}$ and $3 \mathrm{~b}$, with the first composed of those stations not impacted or only impacted after September. The second is of stations showing reduction of species richness (from 10 to 7 species at station 2) or density (from 316 to 122 ind $0.078 \mathrm{~m}^{-2}$ at station 3 ) in November compared with September. These two groups presented the highest number of species (17 species and 13 species, respectively) and were dominated by the same ones: H. australis and $K$. schübartii. Group 4 comprised samples from stations 1, 3, 4, and 5 on the March cruise, confirming the recovery of the assemblages approximately six months after the event at all stations, except station 2. This group had 12 species and was dominated by juveniles of $H$. australis that comprised approximately $96 \%$ of total organisms.

Even though they presented reduced density of organisms during all cruises, the samples from station 5 were included in groups $3 \mathrm{a}$ and 4, probably because at this station the number of species and the dominant species were similar to those found for those groups at the other stations.

\section{DISCUSSION}

The Lagoa dos Patos is a large choked lagoon (Kjerfve, 1986) with a long, narrow entrance channel, reduced tidal oscillations ( $0.5 \mathrm{~m}$ of tidal range), long flushing events, dominant wind forcing, and intermittent stratification events due to runoff and rainfall. Highly variable salinity characterizes the estuarine region as very unstable chemically (Niencheski \& Baumgarten, 1997). These environmental conditions contribute to the low macrobenthic fauna diversity as shown by other works recording a maximum of 40 species in the estuarine region (Capitoli et al., 1978; Rosa-Filho \& Bemvenuti, 1998; Bemvenuti \& Netto, 1998).

Typical estuarine invertebrates are represented by about 15 species in the Patos Lagoon (Capitoli et al., 1978). The main infaunal component is Kalliapseudes schubartii, a suspension feeder tanaid living in deeper $(15 \mathrm{~cm}) \mathrm{U}$-shaped tubes of sandy mud bottoms, and attaining densities of 1,000 ind. $\mathrm{m}^{-2}$ in subtidal soft bottoms. 


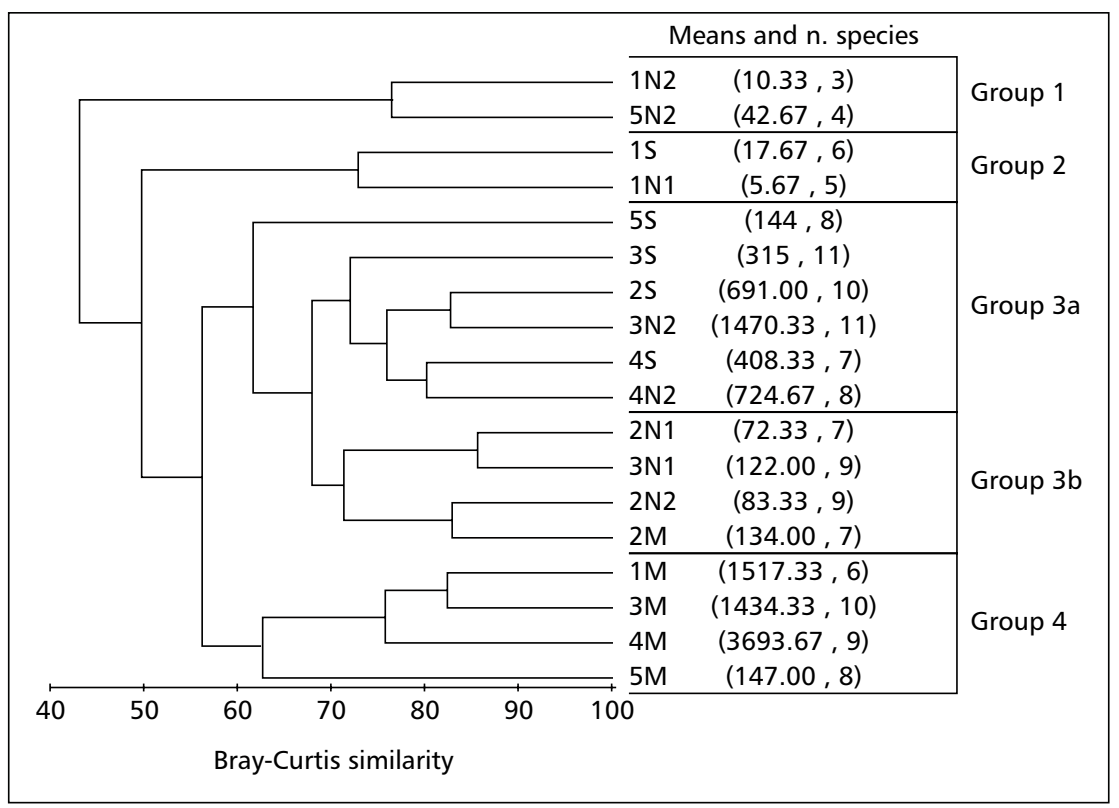

Fig. 6 - Dendogram of Bray-Curtis similarity. The letters denote the sampling month (S: September, N: November, and M: March). The number before the letter denotes the sampling station and the number after the letter denotes the time in the month the sampling took place $\left(1=\right.$ early and $2=$ late). Means (ind $0.078 \mathrm{~m}^{-2}$ ).

Another infaunal component with significant densities in this habitat is the deposit feeder polychaete Heteromastus similis which digs quite deeply in the sediment (up to $15 \mathrm{~cm}$ depth). This species and the errant burrowing detritivorous predator polychaete Nephtys fluviatilis both attain densities between 200 and 244 ind. $\mathrm{m}^{-2}$ in subtidal estuarine bottoms. Another conspicuous infaunal organism is the suspension feeder pelecypod Erodona mactroides, that may occur in densities between 500 and 1,000 ind. $\mathrm{m}^{-2}$ in the estuarine infralittoral (Bemvenuti et al., 1978).The main estuarine epifaunal component, the surface deposit feeding gastropod Heleobia australis, attains densities that may exceed 40,000 ind. $\mathrm{m}^{-2}$ in subtidal bottoms, though pronounced spatial and temporal density changes are common (Bemvenuti et al., 1978; Lana, 1986).

The major marine macrofaunal components in the subtidal and channel estuarine bottoms are mainly polychaetes (i.e., Sigambra grubii, Onuphis setosa, Magelona riojai, Hemipodus olivieri, Americonuphis sp.) and peracarid crustaceans, represented by isopods (Synidotea marplatensis) amphipods (Bathyporeiapus bisetosus), and cumaceans (Dyastilis sympterigiae) (Bemvenuti, 1997a).

The low number of macrobenthic species collected in this work (22 spp.) from 54 samples taken at five sites on four occasions reflects the stressful conditions in the subtidal bottom and channel of the Rio Grande Harbor area. The species composition and richness are similar to that recorded by Bemvenuti et al. (1992), who collected 21 species during two years of bi-monthly benthic macrofauna monitoring at two sampling points located in the same area.

When analyzing the effects on macrobenthic assemblages of the acid discharge from the NT Bahamas, different times of impact can be distinguished along the sampling stations: 1) an immediate impact, i.e., occurring during acid discharge into the water, as at station $1 ; 2$ ) delayed impact, as at station 2; and 3) absence of direct impact, as on the remaining sampling points. 
It is generally recognized that $\mathrm{pH}$ is one of the major factors determining the distribution patterns of aquatic invertebrates species (Hall et al., 1988). Toxic effects associated with acid conditions in invertebrate species include impaired salt balance and calcium metabolism, reduced gas exchange, and element deficiencies, even though in invertebrates the physiologic mechanisms involved are not clearly known (Merrett et al., 1991; Howell, 1990). Abel (1996) reports that it is generally accepted that as $\mathrm{pH}$ decreases, biodiversity and productivity decreases can be observed in aquatic systems.

Stations 1 and 2, close to the NT Bahamas, were located inside the area considered to be directly affected by the acid mixture discharge. In this area, $\mathrm{pH}$ measurements exhibited values below 5.0 in the bottom sediments during the discharge. In the same period, Montú \& Gloeden (1998) recorded a water column $\mathrm{pH}$ of 3.12 at the surface and 3.05 at the bottom. Under these conditions, these authors found copepods with ruptured carapace and intestinal prolapsis, and cladocerans, evidencing oxygen deficiencies for respiration and shawing strong signs of egg and embryo loss. Thus, Montú \& Gloeden (1998) considered the water column at stations 1 and 2 as degraded environments.

Station 1 had few species and low densities of benthic macrofauna during the spill, a situation worsening during the cruises in November. At that station, the more common benthic invertebrate was the subsurface deposit feeding polychaete Heteromastus similis, which builds galleries into deeper sediment strata ( $15 \mathrm{~cm}$ depth). This life strategy affords refuge from macroepifaunal predators in soft bottom sediments (Bemvenuti, 1987) and may likely prevent contact of the polychaete with the acid water conditions on the sediment surface.

The small species number and low macrofaunal densities continued until the summer of 1999. In the final cruise in March 1999 we observed a recovery with the settlement of juveniles of the dominant species. This situation was well characterized by the superficial deposit feeder gastropod $H$. australis, which is the main dominant species on sublittoral sand-muddy bottoms of the Patos Lagoon estuary (Bemvenuti et al., 1992; Bemvenuti, 1997a), but which was almost absent from the area close to the NT Bahamas at the time of the acid discharge. This result agrees with Okland (1992) who, in studying the effects of acidification on freshwater gastropods, found the group absent in lakes with $\mathrm{pH}$ lower than 5.2. The author further mentions the disappearance of three species, paralleling $\mathrm{pH}$ reduction from 5.2 to 4.2.

Heleobia australis, as well as other members of the Hydrobiidae family, can float using the water surface tension (Green, 1968; Newell, 1971). This displacement capacity added to the opportunistic behavior of this species (Lana, 1986; Bemvenuti et al., 1992) allow it to invade new areas or avoid excessively stressful situations (Bemvenuti et al., 1992). The result is the absence of the species from heavily contaminated areas. The low densities of H. australis near the NT Bahamas in the September and November of 1998 samples can be similarly explained: they may have been due to its migration away from the acid plume. This hypothesis has still more support when it is observed that in March 1999, six months after the spill, that species abundance reached density values similar to those observed by other authors during normal conditions in the estuarine sublittoral (Bemvenuti et al., 1978, 1992; Bemvenuti, 1997a; Rosa-Filho \& Bemvenuti, 1998). Although it is likely that molluscs with calcareous shells will be either damaged or will avoid low $\mathrm{pH}$ areas in freshwater environments (Okland, 1992), there are no other case studies indicating that this is the case in the marine/estuarine environment.

At station 2, the samples obtained during the discharge in the September cruise showed macrobenthic densities greater than those of the majority of benthic habitats in the main body of the lagoon's estuarine region (Bemvenuti et al., 1992; Bemvenuti, 1997a; Bemvenuti \& Netto, 1998; Rosa-Filho \& Bemvenuti, 1998). Conversely, sampling in November showed density reductions of the dominant species. This effect, verified in the macrobenthic assemblages affected by the acid discharge fits observations of Abel (1996), who recognized that $\mathrm{pH}$ decrease can cause a reduction in the number of species and even biotic community structural alterations.

During the November cruise, an absence was also observed of recruitment of the dominant species, the deposit feeder gastropod Heleobia australis, contrary to what is expected in spring and summer shown by Bemvenuti (1997b) and Bemvenuti \& Netto (1998). This absence of recruitment agrees 
with observations of several authors who demonstrated that the embryonic stages of snails are very sensitive to low $\mathrm{pH}$ (Holcombe et al., 1984; Servos et al., 1985). Shaw \& Mackie (1990) observed that all embryos of the gastropod Amnicola limosa kept at $\mathrm{pH} 4.5$ failed to hatch and eggs kept at $\mathrm{pH} 5.5$ experienced reduced hatching success and delayed development.

At stations 3, 4, and 5, which were outside the area considered directly influenced by the acid discharge of the NT Bahamas, the species composition, species number, and density of macroinvertebrates exhibited values, even during the acid discharges, similar to those of other studies on benthic macrofauna in the sublittoral and channel of the estuarine region of Patos Lagoon (Bemvenuti et al., 1992; Bemvenuti \& Netto, 1998; Rosa-Filho \& Bemvenuti, 1998).

At stations 3 and 4, which had more species and also higher densities, there was a large increase in the total macrofauna abundance due to intense recruitment of the two dominant species, $H$. australis and $K$. schübartii, recorded from the end-ofNovember cruise onwards. This observations agrees with those of other studies recording recruitment peaks for these species during spring and summer in the area (Bemvenuti, 1997b; Bemvenuti \& Netto, 1998). The recruitment success resulting from two kinds of development, one in pelagic larvae of the opportunistic gastropod $H$. australis, and the other, direct, due to embryo protection by marsupial spawning of local tanaid $K$. schubartii populations, indicates that the macrobenthic assemblage in these areas was not affected directly by the acid discharge from the NT Bahamas.

At station 5, at an $18 \mathrm{~m}$ depth, in the September and March cruises organism density was lower than at stations 3 and 4, even though species richness was similar. At this station, the sampling at the end of November revealed a poorly sorted bottom sediment with a great amount of shells. Both species richness and benthic macrofauna densities of these samples were lower than those recorded at the same place on other sampling occasions, all of which were on sand-muddy bottoms. Bemvenuti et al. (1992) found that the benthic assemblages in the Patos Lagoon channels with biodetritical bottoms exhibit a reduced number of species with low densities and temporal persistence. Substrata with these cha- racteristics reflect high hydrodynamic action which produces instability in the bottom and prevents organic matter accumulation. Thus limiting available food for deposit-feeding species (Levinton, 1995).

The present results here partly agree with previous observations (Bemvenuti et al., 1992; RosaFilho \& Bemvenuti, 1998) showing that the composition and richness of benthic macrofauna species of the are clearly influenced by lagoon geomorphological and climatic characteristics. In addition, densities are affected by the substratum characteristics \& biological processes (Bemvenuti, 1997b; Rosa-Filho \& Bemvenuti, 1998; Bemvenuti $\&$ Netto, 1998), which allowed recruitment to be identified in this work. However, in the area influenced by the pollutant emissions from the NT Bahamas, the structure and dynamics of the macrobenthic assemblages were found to be altered during the two first months after the discharge.

Acknowledgments - This work was supported by grants to the authors from CAPES and CNPq, the Brazilian financial support agencies. The authors are grateful to Nilton Abrel for help during field and laboratory activities, to Dr. Paulo M. Baisch for providing $\mathrm{pH}$ and $\mathrm{Eh}$ data, and to Leandro Bugoni and Dionéia César for the extensive discussions on the manuscript. Our special thanks to Dr. José H. Muelbert and an anonymous reviewer for the critical reading and suggestions on the manuscript.

\section{REFERENCES}

ABEL, P. D., 1996, Water pollution biology. John Wiley and Sons, New York.

BAUMGARTEN, M. G. Z. \& NIENCHESKI, L. F., 1990, Avaliação da capacidade bioindicadora de Balanus improvisus para os metais chumbo, cobre e manganês presentes no estuário da Lagoa dos Patos (RS, Brasil). Atlântica, 12: 5-32.

BEMVENUTI, C. E., CAPITOLI, R. R. \& GIANUCA, N. M., 1978, Estudos de ecologia bentônica na região estuarial da Lagoa dos Patos. II - Distribuição quantitativa do macrobentos infralitoral. Atlântica, 3: 23-32.

BEMVENUTI, C. E., 1987, Predation effects on a benthic community in estuarine soft sediments. Atlântica, 9(1): 5-32.

BEMVENUTI, C. E., CATTANEO, S. \& NETTO, S. A., 1992, Características estruturais da macrofauna bentônica em dois pontos da região estuarial da Lagoa dos Patos, RS, Brasil. Atlântica, 14: 5-28.

BEMVENUTI, C. E., 1997a, Benthic invertebrates. In: U. Seeliger, C. Odebrecht \& J. Castello (eds.), Subtropical convergence marine ecosystem. The coast and the sea in the warm temperate southwestern atlantic, Springer Verlag, Heidelberg, pp. 43-46. 
BEMVENUTI, C. E., 1997b, Unvegetated intertidal flats and subtidal bottoms. In: U. Seeliger, C. Odebrecht \& J. Castello (eds.), Subtropical convergence marine ecosystem. The coast and the sea in the warm temperate southwestern atlantic, Springer Verlag, Heidelberg, pp. 78-82.

BEMVENUTI, C. E. \& NETTO, S., 1998, Distribution and seasonal patterns of the sublittoral benthic macrofauna of Patos Lagoon (South Brazil). Revista Brasileira de Biologia, 58: 211-221.

CAPITOLI, R. R., BEMVENUTI, C. E. \& GIANUCA, N. M., 1978 Estudos de ecologia bentônica na região estuarial da Lagoa dos Patos. I. As comunidades bentônicas. Atlântica, 3: 5-22.

CLARKE, K. R. \& WARWICK, R. M., 1994, Changes in marine communities: an approach to statistical analysis and interpretation. Natural Environmental Research Council, Plymouth.

CLOSS, D., 1962, Foraminiferos e tecamebas da Lagoa dos Patos. Bol. Esc. Geol., 11: 1-130.

FIELD, J. G., CLARKE, K. R. \& WARWICK, R. M., 1982, A practical strategy for annualizing multispecies distribution patterns. Mar. Ecol. Prog. Ser., 8: 37-52.

GARCIA, C. A. E., 1997, Hydrographic characteristics. In: U. Seeliger, C. Odebrecht \& J. Castello (eds.), Subtropical convergence marine ecosystem. The coast and the sea in the warm temperate southwestern atlantic, Springer Verlag, Heidelberg, pp. 18-20.

GREEN, J., 1968, The biology of estuarine animals. Sidgwick and Jackson, London.

HALL, J., LIKENS, G. E., FIANCE, S. B. \& HENDREY, G. R., 1988, Experimental acidification of a stream in the Hubbard Brook Experimental Forest, New Hampshire. Ecology, 61: 976-989.

HOLCOMBE, G. W., PHILIPS, G. L. \& MARIER, J. W., 1984 Methods for conducting snail (Amplexa hypnorum) embryo through adult exposure effects of cadmium and reduced $\mathrm{pH}$ levels. Arch. Env. Contam, Toxicol., 13: 627-634.

HOLME, N. A. \& McINTYRE, A. D., 1984, Methods for the study of marine benthos. Blackwell Scientific Publications, New York.

HOWELL, G., 1990, Acid rains and acid waters. Ellis Horwood, New York.

KJERFVE, B., 1986, Comparative oceanography of coastal lagoons. In: D. A. Wolfe (ed.), Estuarine variability. Academic Press, New York, pp. 63-81.
LANA, P. C., 1986, Macrofauna bêntica de fundos sublitorais não consolidados da Baía de Paranaguá (Paraná). Nerítica, 1: 79-89.

LEVINTON, J. S., 1995, Marine biology: function, biodiversity, ecology. Oxford University Press Inc., New York.

LONERGAN, S. P. \& RASMUSSEN, J. B., 1996, A multitaxonomic indicator of acidification: isolating the effects of $\mathrm{pH}$ from other water-chemistry variables. Can. J. Fish. Aquat. Sci. 53: 1778-1787.

MERRETT, W. J., RUTT, G. P., WEATHELEY, N. S., THOMAS, S. P. \& ORMEROD, S. J., 1991, The response of macroinvertebrates to low $\mathrm{pH}$ and increased aluminium concentrations in Welsh streams: multiple episodes and chronic exposure. Arch. Hydrobiol., 121: 115-125.

MONTÚ, M. A. \& GLOEDEN, I. M., 1998, O derramamento ácido do navio NT Bahamas e as primeiras consequiências sobre o zooplâncton do estuário da Lagoa dos Patos (Rio Grande, RS). Nauplius, 6: 195-197.

NEWELL, C., 1971, Biology of intertidal animals. Pauk Elek Limited, London.

NIENCHESKI, L. F. \& BAUMGARTEN, M. G., 1997, Environmental Chemistry. In: U. Seeliger, C. Odebrecht and J. Castello (eds.), Subtropical convergence marine ecosystem. The coast and the sea in the warm temperate southwestern atlantic, Springer Verlag, Heidelberg, pp. 20-23.

OKLAND, J., 1992, Effects of acid water on freshwater snails: results from a study of 1000 lakes throughout Norway. Environmental Pollution, 78: 127-130.

PILLAY, T. V. R., 1993, Aquaculture. Principles and practices. Blackwell Scientific Publications Limited, Oxford.

PRICE, E. E. \& SWIFT, M. C., 1985, Inter- and intra-specific variability in the response of zooplankton to acid stess. Can. J. Fish. Aquat. Sci., 42: 1749-1754.

ROSA-FILHO, J. S. \& BEMVENUTI, C. E., 1998, Caracterización de las comunidades macrobentónicas de fondos blandos en regiones estuarinas de Rio Grande do Sul (Brasil). Thalassas, 14: 43-56.

SERVOS, M. R., ROOKE, J. B. \& MACKIE, G. L., 1985, Reproduction of selected Mollusca in some low-alkaline lakes in south-central Ontario. Can. J. Zool., 63: 511-515.

SHAW, M. A. \& MACKIE, G. L., 1990, Effects of calcium and $\mathrm{pH}$ on the reproductive success of Amnicola limosa (Gastropoda). Can. J. Fish. Aquat. Sci., 47: 1694-1699. 